\title{
AN ANALYTICAL VIEW OF THE PSYCHOLOGICAL IMPACT OF USING SOCIAL MEDIA ON THE YOUTH OF KARACHI
}

\author{
Wajiha Raheeq \\ Ph.D Scholar \\ Co operative Teacher \\ Department of Social Work \\ University of Karachi \\ Karachi-Pakistan \\ wajiharaheeq@hotmail.com \\ Mohammad Noman Sheikh \\ M.Phil Scholar \\ Co operative Teacher \\ Department of Social Work \\ University of Karachi \\ Karachi-Pakistan \\ noman.trainer@gmail.com \\ Dr. Nadia Faizan \\ Teaching Associate \\ Co operative Teacher \\ Department of Social Work \\ University of Karachi \\ Karachi-Pakistan \\ nadia20dec@yahoo.com
}

\section{Abstract}

The current study was intended to analyse the impact of social media on mental health of the youth in city of Karachi. The study employed a primary quantitative research method in which survey questionnaire was designed on the basis of five distinct dimensions of independent variable i.e., academic purpose, socialisation, entertainment, informativeness, and constraints. A total of 100 participants were selected for survey, which belonged to three separate groups i.e., 40 studying at intermediate level, 40 studying at graduation level, and 20 not currently studying but employed in the labour market. Statistical analysis was conducted through SPSS software in which independent t-test, ANOVA, and correlation analysis were conducted. The ANOVA results obtained showed that in that sig value is highly insignificant which indicates that there is low variance and thus groups are not statistically different. After confirmation of insignificant variation, correlation analysis indicated that academic purpose had low association with mental health of youth in Karachi. Whereas, association of socialisation, entertainment, 
informativeness, and constraints were found to be high, thus indicating their high impact on mental health of young individuals of the city.

Keywords: Social Media, Mental Health, Karachi, Socialization, Youth, Informativeness.

\section{Introduction}

The modern approaches in the technology and advancement of social media havea greater impact on individuals in terms of psychological and social perspectives. It has been observed that there is a significant impact of social media on the youth because users of social media are younger (Arendt, Scherr \& Romer, 2019).In the recent decade, the number of social media users in the world have been increased due to essay access and globalisation in which people can easily communicate. The youth is most affected by the use of social media because they are more likely to use social media due to the personal and collective interest in the socialisation context (Sabermajidi et al., 2019).

The advancement in the social media features and channels in recent years including Facebook, Twitter, Instagram, WhatsApp and TikTok have increased the numbers of users in the world and it has developed a psychological impact that has increased the aggression, socialisation and intersections among the youth (Wirth, 2020). In these terms, it has been critically analysed that social media platforms have both negative and positive psychological impacts on the youth and it led to social media and internet additions among the elderly age individuals from 15-30 years (Gupta \& Purohit, 2020).It has been evaluated through the research that young adults who are studying in college and universities are more likely to use the social media channels for communication and it has led to the different psychological impacts in terms of anxiety and existent which are both negative and positive aspects.

In the case of Pakistan, in recent year's use of social media has been increased due to different circumstances including the essay access to social media, technology advancement, and purpose of entertainment, study, jobs, socialisation and influences of the society. Pakistan is a developing state in which the elderly people are not more familiar with the use of technology and educated as compared to the developed states including the USA and the UK (Sheikh, Sheikh \& Soomro, 2016).Therefore the youth in Pakistan specifically in the big cities including Karachi, Lahore and Islamabad have influenced social media and started the use of these tools at the broader level and found to be addicted from the excessive use of social media and has resulted in psychological issues and fatigue to made the effective decagons because exaggeration and overgeneralisations of news including the fake materials have negatively impacted the youth of Pakistan (Sultana, Ghaffar \& Saman, 2019).

The use of social media among the young individuals in Pakistan including the youth of Karachi has a significant psychological impact and led to physical health issues. Mustafa (2018) has conducted a detailed study on the impact of social media on the youth of university students. 
According to this study, it has been explored that there is a positive psychological impact of social media in terms of being more positive, socialises and innovation but there is another side of the excessive use of the social media channels. It is important to use the channels of social interactions based on the purpose and limited time because excessive use of social media is leading to fatigue and psychological distress including low self-esteem, stress and anxiety (Malik et al., 2020). These are results from the fake news, overgeneralisations of the facts and findings including the privacy issues.

It has been noticed that proper and purposeful use of the social media in the youth of Pakistan socially in the Karachi youth has a positive psychological impact in motivating the youth towards the positive deeds, increase in the confidence and the self-esteem which is enabling them to control the aggression and critically review the things on the social media (Ahmed, Ara\& Tajjamul, 2016). It is also observed that social media use in Pakistan is leading towards women psychological wellbeing and empowering them to lead from the front in different social and business activities. Recognition at the national level for women is a psychological appreciation to motivate them for effective contribution to the country development and this happened in the last few years through social media channels (Tahir, Baig \& Ahmer, 2020). In this way,the current study has the aim to critically evaluate the psychological impact of social media use among the youth of Karachi through the analytical approach. In this way, both the negative and positive psychological impacts are evaluated in the current study to resolve the psychological, privacy and confidential problems of the Karachi youth.

\section{Rationale}

It is observed and evaluated from the past literature and findings that technology advancement in recent times is rapidly increasing and resulted in the global village in which people are communicating with each other through virtual tools. Social media channels including Facebook, Instagram, Whatsapp and Skype are the vital social media channels that are used by the youth of the world. These sources of communication and socialisation have different pros and cons in terms of psychological impact, privacy concern and physical health including motivation and aggression (Tahir, Baig \& Ahmer, 2020). It is mainly affecting the youth and Pakistan is a developing country where the young generation is more likely to use these channels and counter with the psychological issues due to the excessive use of these social media platforms.

Karachi is the larger city of Pakistan where the youth is high in numbers as compared to the elderly people and they are the future assets of the nation and earnings for the families. In this way, it is important to conduct the studies to explore the positive and purposeful use of social media and make a positive change in the country development. Psychological issues due to overthinking, cognitive dissonance and mistrust through social media is leading to serious psychological issues and damaging the youth of Karachi (Ahmed, Ara \& Tajjamul, 2016). It is important to be aware of the youth through proper channels and train them to get the use of social media just for the purpose and not waste more time on these activities. Although there isan effective and positive use of social media including social media marketing, online purchasing 
and selling (Mustafa, 2018). These things should be used by the youth of Karachi to alter the psychological impact in the positive aspect and make the positive and optimal use of these tools. This study deal with these issues as the major concern and the study hypothesis is tested by collecting the data from the concerned population.

\section{Literature Review}

As a web-based instrument, social media is the best way of social interaction where the sharing of information is done digitally and provide ease to those who feel isolated or marginalised. The use of information technology in social media has successfully enhanced the attractiveness of youth (Mustafa, (2018). However, there is a psychological impact of social media on youngsters living in Karachi youth. As the case study is conducted in the youth of Karachi. Considering social media as a major contributor to improving the standard of living as it supports global access to the existing market. This social accessibility is an opportunity for the community to connect all over the world but has social issues in developing countries such as Pakistan (Anam Iqbal \& Iqbal, K. (2017). For this reason, the country has the responsibility of accountability and investigation to make things better and effective. Cyberbullying, social media comparisons and sleep deprivation are the more associated negative impacts faced by young people because of social media along with mental health problems and self-esteem. Rabia et al.(2020) has investigated that the influence of social media on teenagers is more problematic as the internet has now changed the way it presents the graphics which negatively impacts the youth. The experiment shows that about $57 \%$ of the 9 to 19 years of young generation of Pakistan is more connected with such websites which displays sexual excitements and automatically effects the human mind as well.

Different social media networking sites are effectively used by individuals with permanent connections, for this survey conducted in 2019, by Martian Armstrong, five social networks have been ranked which impacts the mental health of young people. the results state that YouTube is the most positive network which has net positive influences rather the other while another Twitter, Facebook, Instagram and Snapchat has a net negative impact which is established because of the 14 ranking factors include; the opportunity to express selves, the harassment, self-image, depression, anxiety and loneliness (Statista, (2021). 


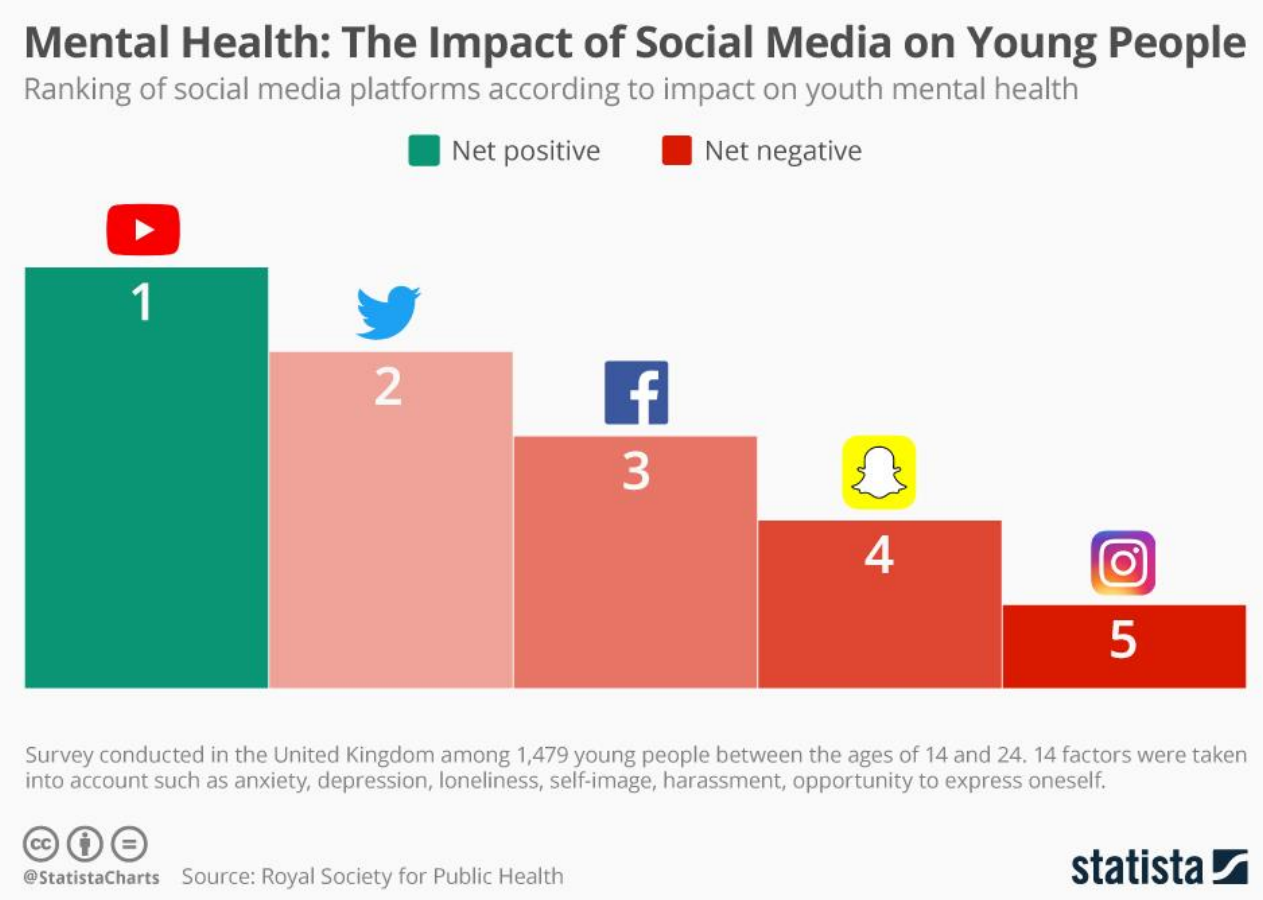

Figure 1: impact of social media on young people

Source: Statista Infographics. (2021)

Tariq et al., (2012) said that, although, the social media networking sites provide a platform to the young generation to discuss major issues which have been increased with time and it received popularity among youth. People are more engaged with social media without thinking about its psychological impacts on youth lives. Social media affects youth in both ends positively and negatively as when the youth uses social media gateway to share the negative information to connect in the society and started to do immoral activities. Karachi is a big city of Pakistan where the hub of businesses has been growing and social media become a need for every individual either for working propose or learning purposes. From the studies of Newport Academy (2021) on social media usage and its impacts on young people, social media is a cultural craze where the awareness where most of the people think that it is an educational tool provides awareness on latest trends. Several social channels such as Facebook, Twitter, YouTube, reedit, Instagram, snap chat and Pinterest have been used by the youth of Pakistan. Considering as need for companionship with people of mutual interests, social connections are considered as a strengthen way which has a significant impact on individual mental health. Connecting socially with others ease stress, anxiety and depression while boosting life, joy and comfort. While each has benefits, but it is necessary to understand it is not an effective replacement with the real world as it has serious impacts on mental as well as emotional health.

Establishing the long term consequences of social media either are good or bad, several studies has investigated the long term negative impact on youngsters of social media. Marchant 
et al., (2017) has stated that there is a strong relationship between human mental health and the heavy use of social media. Young people more addicted to social media has an increased level of risk for self-harm, suicidal thoughts, anxiety and depression. A recent study conducted by Bibi, Blackwell \& Margrave (2021) has states the psychological effects of social media impact on teenage girls, where they started to use social media by the age of 13 and the impacts and the impacts recorded from their experiences and mood include inadequate sleep, the exposure to cyberbullying and less participation in the physical activities. The study by Glazzard \& Stones, (2019) has reported that there are 17\% of female youngsters are struggling with psychological stress and as compared to boys. From the beginning of 2010, the usage of the smartphone has been increased and the increased cyberbullying effect on young individuals is because of several symptoms such as depressive effects, anxiety factor, loneliness and suicidal behaviour and some physical issues including headaches or internal problems such as stomachaches. Another psychological effect of social media is sleep deprivation which increases physical and mental stress which increases depression in youngsters, risk-taking behaviour and substance abuse while reducing human emotional thinking and regulation skills.

From a psychological distress and social media usage, a study conducted by Arikan, Acar \& Ustundag-Budak, (2022) on undergraduate students of university has investigated that most of the youngsters are dependent on the use of social media and acquires knowledge, learning and to define their identities by full filling the needs and wants. Suggesting the evidence on the direct relationship of social media usage on mental health such as anxiety, depression and loneliness. Similarly, another study has been conducted by (Asibong et al., (2020), where an experiment is conducted on the 702 young adults and coming in the age range starting from 18 to 45 at longitudinal scale, where about $33 \%$ of the community was reported the patients with depression.

Summarizing the whole opinions, the perspectives of different authors, the psychological effects of social media has a great threat as well as the opportunities on the youngsters at multiple levels. Significantly, in developing countries, the use of social media has created problems of unethical pictures, the unwanted pictures or anti-religious posts causes deterioration in different communities.

\section{Conceptual framework}

Conceptual framework is design of variables through which the researcher decides and describes the independent and dependent variables involved in the research. In this study, the conceptual framework is given below, which elaborates decomposition of the independent variable. The independent variable was impact of social media, which was further factorised in five distinct dimensions, which tested the influence of social media on mental health of youth through five different aspects. These dimensions were academic purposes, socialisation, entertainment, informativeness, and constraints. Meanwhile, the dependent variable was psychological or mental health of Karachi youth. 


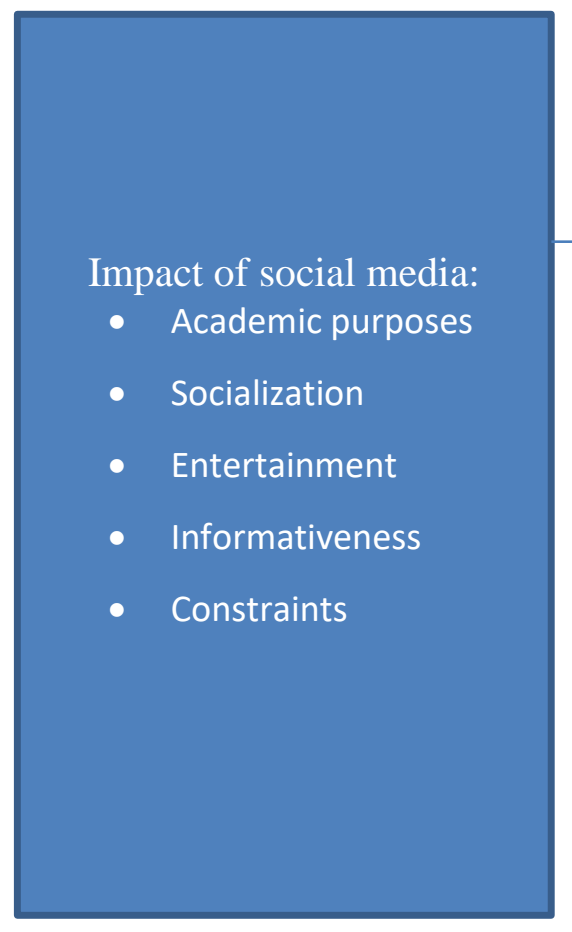

\section{Objectives of the study}

The determination of analytical view of the psychological impact of social media usage on young people of Karachi.

\section{Delimitation}

The major delimitation of this research is that the diverse population of different demographics from Karachi will be selected to conduct the longitudinal and crossectional research.

\section{Hypothesis}

$\mathrm{H} 0=$ there is no psychological impact of social media on young people living in Karachi $\mathrm{H} 1=$ there is a positive psychological impact of social media on young people living in Karachi $\mathrm{H} 2=$ there is a negative psychological impact of social media on young people living in Karachi

\section{Methodology}

For the conduction of credible results, a set of rules and procedures will be adopted by the researcher to make to collect, analyse and interpret the relevant information into useful and processed information. For the conduction of this research, the plan will be followed to carry out the research which takes the things making a collection of data from the selected population. As a primary and quantitative approach, this research will be more valid, accurate and updated information which reveals the accurate trends of the thoughts, experiences and perceptions of the 
individuals using social media. The experimental research design was adopted by the researcher to understand and evaluate the influence of social media on young people. The correlational design was used to analyse and investigate the relationship between social media usage and its psychological impact on young people living in Karachi. The treatment group which is also known as the experimental group will have consisted of 100 young individuals living in Karachi. Mainly the focused group will be divided into two main categories, youth enrolled in college and universities and the second group will have consisted of the young people belonging to the working class. After taking classes, the random sampling technique will be utilised to select the individuals enrolled in college and universities in different programs from any institute of Karachi and youth in the labour market who lies under the age group of 18 to 30. The longitudinal and crossectional study will be done to investigate the psychological risk factors in youth because of excessive use of social media.

\section{Variables}

The dependent and independent variable has a significant impact on the conduction of valid and reliable research. Mental health, Karachi, the impact of social media and youth are the main variable of this research. Impact of social media is anindependent variable while the psychological or mental health of Karachi youth is an dependent variable in this research.

\section{Population and sample}

For valuable and valid research findings, it is decided that, from the total of 100 observations, 100 participants will be selected from different public colleges, universities and workplaces through a random sampling technique while specifying the number of individuals from each area. Diversified results based on gender as well and the workplace will be discussed in this research which strengthen the results to the reader about the psychological health of youth in Karachi. The sample consist of 20 females and 20 males who were studying at an intermediate level at a public college in Karachi. In addition to this, 20 males and females enrolled at graduation level at a public university in Karachi. While the 20 participants will be selected from the youth who are not studying in any of the institutes while belonging to the same age group at about market. So, it will be convenient for the researcher to conduct experimental research on youth in educational institutes as well as in the labour market.

\section{Instrument}

For detailed and strong results, the questionnaire will be developed which consisted of 20 questions that incorporate the dependent and independent variables. Both open and close-ended questionnaires will be developed on five dimensions as the questions on the use of social media for academic purposes, for socialization, entertainment, informativeness and constraints. Each dimension in the questionnaire will give the knowledge about which type of people are using social media and which type of scenarios they have faced because of that use. The data will be 
collected with the consent of each individual. The five dimensions of the questionnaire are challenging to learn but help the researcher to make the gender-based analysis on how and who are suffering from cyberbullying, anxiety, sleep disorders, stress and other societal risks.

\section{Procedure}

The questionnaire technique will be used for data collection, where the researcher will develop the online questionnaire and send them to the target audience (Krosnick, (2018). Data will be collected within one month of the period. the open and close-ended questions give helps students to explain what they have learned through social media and which type of negative experience they have suffered while developing trust with the participant on to use their information solely for academic purpose. After the collection of data, to make the analysis, the statistical tools and techniques will be used through which the accuracy and validity of each item of the questionnaire will be tested. Using the SPSS, the ANOVA, t-test, independent t-test and correlation will be tested. The experiment group of 100 students and a young labour workforce will be selected from different institutes and workshops situated in Karachi. The results will be described by using deductive reasoning by exploring the hypothesis to test whether the statement is valid or not.

\section{Results}

\section{Demographics analysis}

Demographics analysis is a vital component of statistical examination in social science research. It pertains to analysis of the sample population involved in any research. The sample population could vary in terms of agglomeration of gender, race and ethnicity, and other external demographic variables, which may impact the actual results. In the current research, three groups of participants were formed i.e., those studying at intermediate level in a college in Karachi, students of graduation level in Karachi, and those which are not currently studying but are employed in the labour market. In these three groups, as shown in the tables below, the first two groups comprised of 40 participants each, with 20 males and 20 female participants respectively. Meanwhile, the third group consisted of 20 participants working in the labour market, with 10 males and 10 females. 


\section{Gender}

\begin{tabular}{llllll}
\hline & & & & Valid & Cumulative \\
& & Frequency & Percent & Percent & Percent \\
\hline Valid & Females & 50 & 50 & 50 & 50 \\
& Male & 50 & 50 & 50 & 100 \\
& Total & 100 & 100 & 100 & \\
\hline
\end{tabular}

\section{Current education level}

\begin{tabular}{llllll}
\hline & & & Valid & Cumulative \\
& & Frequency & Percent & Percent & Percent \\
\hline Valid & Intermediate & 40 & 40 & 40 & 40 \\
& $\begin{array}{llll}\text { Graduation } \\
\text { Not currently }\end{array}$ & 40 & 40 & 40 & 80 \\
& & & & \\
studying & 20 & 20 & 20 & 100 \\
Total & 100 & 100 & 100 & \\
\hline
\end{tabular}

\section{Working experience}

\begin{tabular}{llllll}
\hline & & & & Valid & Cumulative \\
& & Frequency & Percent & Percent & Percent \\
\hline Valid & 0-1 years & 48 & 48 & 48 & 48 \\
& 1-2 years & 32 & 32 & 32 & 80 \\
2-4 years & 10 & 10 & 10 & 90 \\
More than & 4 & & & \\
years & 10 & 10 & 10 & 100 \\
Total & 100 & 100 & 100 & \\
\hline
\end{tabular}

\section{Independent t-test}


An Analytical View of the Psychological ...

\section{Independent Samples Test}

Levene's Test for Equality of Variances

\begin{tabular}{|c|c|c|c|c|c|c|c|c|c|}
\hline \multirow{9}{*}{$\begin{array}{l}\text { Psychological or } \\
\text { mental health of } \\
\text { youth in Karachi }\end{array}$} & \multirow{6}{*}{$\begin{array}{l}\text { Equal } \\
\text { variances } \\
\text { assumed }\end{array}$} & \multicolumn{2}{|l|}{$\mathrm{Si}$} & \multirow[t]{2}{*}{$\mathrm{df}$} & \multirow[t]{2}{*}{$\begin{array}{l}\text { Sig. } \\
(2- \\
\text { taile } \\
\text { d) }\end{array}$} & \multirow[t]{2}{*}{$\begin{array}{l}\text { Mean } \\
\text { Differ } \\
\text { ence }\end{array}$} & \multirow[t]{2}{*}{$\begin{array}{l}\text { Std. } \\
\text { Error } \\
\text { Differe } \\
\text { nce }\end{array}$} & \multicolumn{2}{|c|}{$\begin{array}{l}95 \% \text { Confidence } \\
\text { Interval of the } \\
\text { Difference }\end{array}$} \\
\hline & & & & & & & & Lower & Upper \\
\hline & & 1. 0 . & - & & & & & & \\
\hline & & $9 \quad 1$ & 1. & & & & & & \\
\hline & & 66 & 60 & & 0.11 & & & - & 0.0766 \\
\hline & & 54 & 6 & 98 & 2 & -0.325 & 0.2024 & 0.72666 & 6 \\
\hline & & & 1. & 96 & & & & & \\
\hline & Equal va & ariances & 60 & .6 & 0.11 & & & - & 0.0767 \\
\hline & not assume & & 6 & 32 & 2 & -0.325 & 0.2024 & 0.72673 & \\
\hline
\end{tabular}

\section{Anova analysis}

ANOVA test is conducted to test the analysis of variance within the data and questions. It compares the means of two independent groups to ascertain whether the means of associated populations are significantly different. In this research, ANOVA test was conducted with respect to two population demographic groups i.e., current education level and work experience. Results of current education level are shown below. The descriptive table indicates that the means are within acceptable range.

\section{Descriptive}

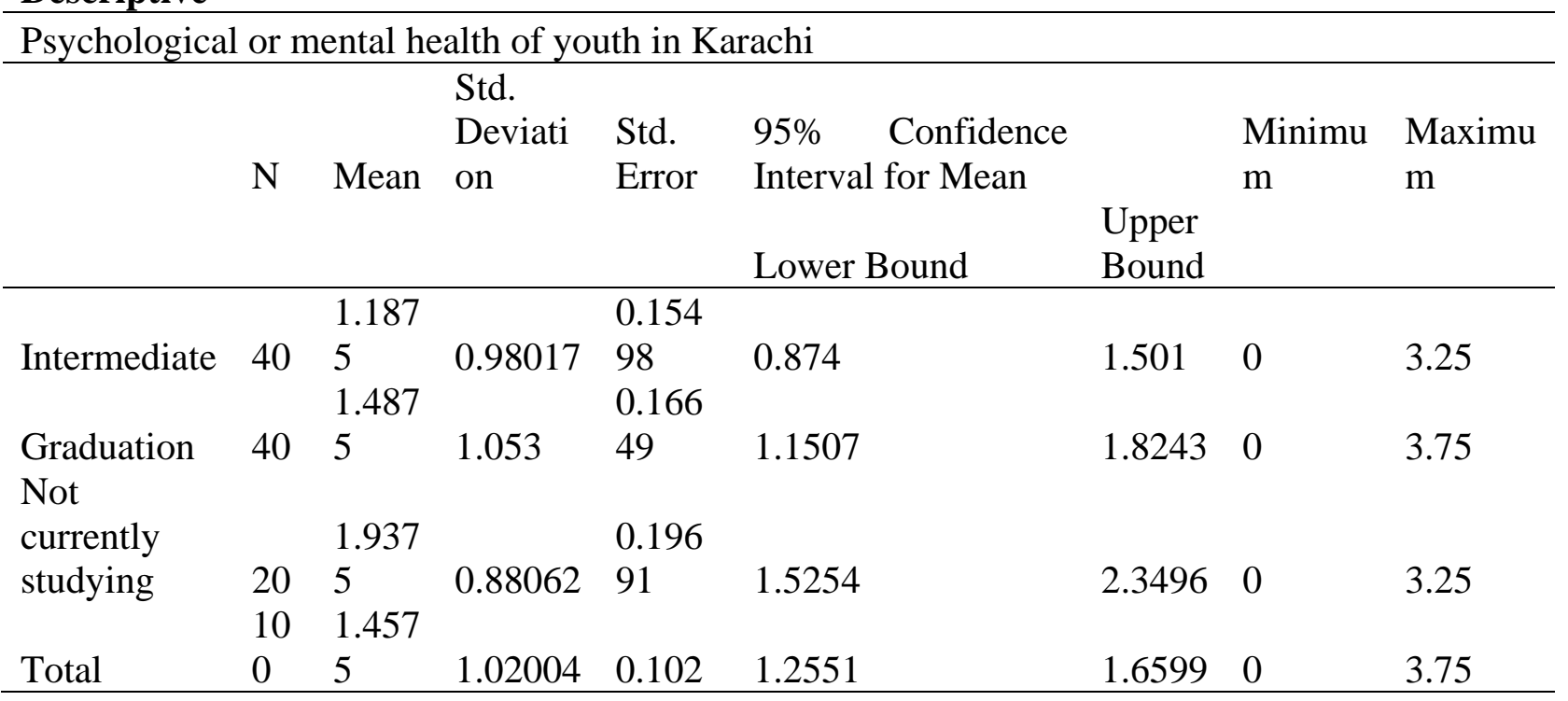


In the next step, test of homogeneity of variance was run through Levene statistic, which determined the significance of variation within the population group. As shown in the table below, sig value is highly insignificant which indicates that there is low variance and thus groups are not statistically different.

\section{Test of Homogeneity of Variances}

\begin{tabular}{|c|c|c|c|c|c|}
\hline \multirow{8}{*}{$\begin{array}{l}\text { Psychological or mental health } \\
\text { of youth in Karachi }\end{array}$} & & \multicolumn{4}{|l|}{ Levene } \\
\hline & & Statistic & df1 & df 2 & Sig. \\
\hline & & & & & 0.32 \\
\hline & Based on Mean & 1.151 & 2 & 97 & 1 \\
\hline & Based on Median & 0.88 & 2 & 97 & $\begin{array}{l}0.41 \\
8\end{array}$ \\
\hline & Based on Median and with & & & & 0.41 \\
\hline & adjusted df & 0.88 & 2 & 96.748 & 8 \\
\hline & Based on trimmed mean & 1.172 & 2 & 97 & 4 \\
\hline
\end{tabular}

The next stage is the ANOVA test for f-table, as shown below. With the table, it can be ascertained that significance of $\mathrm{p}$-value is $0.025<0.05$, indicating that probability of variation happening by chance is low.

The result is shown in the following format:

$\mathrm{F}(2,97)=3.842, \mathrm{p}<0.05$

\begin{tabular}{lllllll} 
ANOVA & & & & & \\
\hline $\begin{array}{l}\text { Psychological or mental health of youth } \\
\text { in Karachi }\end{array}$ & & & & & & \\
& Sum of & & Mean & & \\
& Squares & & df & Square & F & Sig. \\
& & & & & 3.84 & 0.02 \\
Between Groups & 7.56 & 2 & 3.78 & 2 & 5 \\
& & 9 & & & \\
Within Groups & 95.447 & 7 & 0.984 & & \\
& & 9 & & & \\
Total & 103.007 & 9 & & & \\
\hline
\end{tabular}

Then, the post-hoc was conducted to test whether the groups are significantly different from each other, and their results are summarised in the table of Tukey HSD and its summary. As depicted in the subset alpha table, the groups of intermediate and graduation have no significant variation within each other, however, the group not currently studying is statistically different from the other two. It is revealed that the group which is not undergoing any academic pursuits had different perceptions regarding social media impacts. It is attributed that their responses for 
the impact of academic purposes of social media is in contrast to the groups undergoing educational pursuits.

Dependent Variable: Psychological or mental health of youth in Karachi Tukey HSD

\begin{tabular}{|c|c|c|c|c|c|c|}
\hline $\begin{array}{l}\text { (I) Current } \\
\text { education level }\end{array}$ & $\begin{array}{l}(\mathrm{J}) \quad \text { Current } \\
\text { education level }\end{array}$ & $\begin{array}{l}\text { Mean } \\
\text { Difference } \\
(\mathrm{I}-\mathrm{J})\end{array}$ & $\begin{array}{l}\text { Std. } \\
\text { Error }\end{array}$ & Sig. & $\begin{array}{l}95 \% \\
\text { Confidence } \\
\text { Interval } \\
\text { Lower Bound }\end{array}$ & $\begin{array}{l}\text { Upper } \\
\text { Bound }\end{array}$ \\
\hline \multirow{4}{*}{ Intermediate } & \multirow{4}{*}{$\begin{array}{l}\text { Graduation } \\
\text { Not currently } \\
\text { studying }\end{array}$} & & 0.2218 & & & \\
\hline & & -0.3 & 1 & 0.37 & -0.828 & 0.228 \\
\hline & & & 0.2716 & 0.01 & & \\
\hline & & $-.75000 *$ & $\begin{array}{l}6 \\
0.2218\end{array}$ & 9 & -1.3966 & -0.1034 \\
\hline \multirow[t]{2}{*}{ Graduation } & \multirow{2}{*}{$\begin{array}{l}\text { Intermediate } \\
\text { Not currently } \\
\text { studying }\end{array}$} & 0.3 & 1 & 0.37 & -0.228 & 0.828 \\
\hline & & -0.45 & $\begin{array}{l}0.2716 \\
6\end{array}$ & & -10966 & 01966 \\
\hline \multirow{3}{*}{$\begin{array}{l}\text { Not currently } \\
\text { studying }\end{array}$} & & & 0.2716 & 0.01 & & \\
\hline & Intermediate & $.75000 *$ & 6 & 9 & 0.1034 & 1.3966 \\
\hline & Graduation & 0.45 & 6 & 7 & -0.1966 & 1.0966 \\
\hline
\end{tabular}

Tukey HSD

\begin{tabular}{llll}
$\begin{array}{l}\text { Current education } \\
\text { level }\end{array}$ & $\mathrm{N}$ & $\begin{array}{l}\text { Subset } \\
=0.05\end{array}$ & for alpha \\
\hline & & 1 & 2 \\
Intermediate & 40 & 1.1875 & \\
$\begin{array}{l}\text { Graduation } \\
\text { Not currently }\end{array}$ & 40 & 1.4875 & 1.4875 \\
studying & 20 & & \\
Sig. & & 0.473 & 0.19 \\
\hline
\end{tabular}

Afterwards, the same procedure for ANOVA one way test was applied for the case of work experience, to gauge whether the sample population had any variation in results on the basis of variation in their work experience. Descriptive results shown below indicate that means are within acceptable limits. 


\section{Descriptive}

Psychological or mental health of youth in Karachi

\begin{tabular}{|c|c|c|c|c|c|c|c|c|}
\hline & $\mathrm{N}$ & Mean & $\begin{array}{l}\text { Std. } \\
\text { Deviatio } \\
\mathrm{n}\end{array}$ & $\begin{array}{l}\text { Std. } \\
\text { Error }\end{array}$ & $\begin{array}{l}\text { 95\% Confidence } \\
\text { Interval for Mean } \\
\text { Lower Bound }\end{array}$ & $\begin{array}{l}\text { Upper } \\
\text { Bound }\end{array}$ & $\begin{array}{l}\text { Minimu } \\
\mathrm{m}\end{array}$ & $\begin{array}{l}\text { Maximu } \\
\mathrm{m}\end{array}$ \\
\hline & & 1.322 & & & & 1.614 & & \\
\hline 0 - 1 years & 48 & $\begin{array}{l}9 \\
1.359\end{array}$ & 1.00393 & $\begin{array}{l}0.1449 \\
0.1881\end{array}$ & 1.0314 & $\begin{array}{l}4 \\
1.743\end{array}$ & 0 & 3.75 \\
\hline $1-2$ years & 32 & 4 & 1.06434 & $\begin{array}{l}5 \\
0.2813\end{array}$ & 0.9756 & $\begin{array}{l}1 \\
2.136\end{array}$ & 0 & 3.5 \\
\hline $\begin{array}{l}2-4 \text { years } \\
\text { More }\end{array}$ & 10 & 1.5 & 0.88976 & 7 & 0.8635 & 5 & 0 & 3.25 \\
\hline $\begin{array}{l}\text { than } \\
\text { years }\end{array}$ & $\begin{array}{l}10 \\
10\end{array}$ & $\begin{array}{l}2.375 \\
1.457\end{array}$ & 0.64818 & $\begin{array}{l}0.2049 \\
7\end{array}$ & 1.9113 & $\begin{array}{l}2.838 \\
7 \\
1.659\end{array}$ & 1.25 & 3.25 \\
\hline Total & 0 & 5 & 1.02004 & 0.102 & 1.2551 & 9 & 0 & 3.75 \\
\hline
\end{tabular}

The Levene's test for homogeneity of variances, shows the sig value to be much larger than statistical significance of 0.05 , thus verifying that groups had no statistical variance and thus were homogenous.

\section{Test of Homogeneity of Variances}

\begin{tabular}{|c|c|c|c|c|c|}
\hline & & $\begin{array}{l}\text { Levene } \\
\text { Statistic }\end{array}$ & $\begin{array}{l}\mathrm{df} \\
1\end{array}$ & df2 & Sig. \\
\hline \multirow[t]{4}{*}{$\begin{array}{l}\text { Psychological or mental health of } \\
\text { youth in Karachi }\end{array}$} & Based on Mean & 1.291 & 3 & 96 & $\begin{array}{l}0.28 \\
2 \\
0.52\end{array}$ \\
\hline & Based on Median & 0.752 & 3 & 96 & 4 \\
\hline & $\begin{array}{l}\text { Based on Median and } \\
\text { with adjusted df }\end{array}$ & 0.752 & 3 & $\begin{array}{l}89.18 \\
6\end{array}$ & $\begin{array}{l}0.52 \\
4 \\
0.34\end{array}$ \\
\hline & Based on trimmed mean & 1.129 & 3 & 96 & 1 \\
\hline
\end{tabular}

The ANOVA table below. Through the table, it can be ascertained that significance of pvalue is $0.025<0.05$, indicating that probability of variation happening by chance is low. 


\begin{tabular}{llllllll} 
ANOVA & & & & & \\
\hline $\begin{array}{l}\text { Psychological or mental health of youth in } \\
\text { Karachi }\end{array}$ & & & & & & & \\
& Sum & of & & Mean & & \\
& Squares & df & Square & F & Sig. \\
\hline Between Groups & 9.614 & 3 & 3.205 & 3.294 & 0.024 \\
Within Groups & 93.393 & 96 & 0.973 & & \\
Total & 103.007 & 99 & & & & \\
\hline
\end{tabular}

\section{Robust Tests of Equality of Means}

Psychological or mental health of youth in Karachi

\begin{tabular}{lllll} 
& Statistica & df1 & df2 & Sig. \\
\hline Welch & 6.245 & 3 & 27.524 & 0.002
\end{tabular}

The following tables elaborate the test for variation of groups with each other, and its summary is provided in the following table. Through the values, it was revealed that the groups with work experience of 0-1 year and 1-2 years are statistically similar, however, the group of work experience of more than 4 years is different from the other two. This is attributable to different social media experience and its resultant perception in the group working in the labour market, since it is highly likely that only that group would possess working experience of more than 4 years. 
An Analytical View of the Psychological ...

Dependent Variable: Psychological or mental health of youth in Karachi Tukey HSD

\begin{tabular}{|c|c|c|c|c|c|c|}
\hline $\begin{array}{l}\text { (I) Working } \\
\text { experience }\end{array}$ & $\begin{array}{l}\text { (J) Working } \\
\text { experience }\end{array}$ & $\begin{array}{l}\text { Mean } \\
\text { Difference (I- } \\
\text { J) }\end{array}$ & $\begin{array}{l}\text { Std. } \\
\text { Error }\end{array}$ & Sig. & $\begin{array}{l}\text { 95\% Confidence } \\
\text { Interval }\end{array}$ & \\
\hline experience & & & & & Lower Bound & $\begin{array}{l}\text { Upper } \\
\text { Bound }\end{array}$ \\
\hline \multirow[t]{2}{*}{$0-1$ years } & 1-2 years & -0.03646 & $\begin{array}{l}0.2251 \\
0.3428\end{array}$ & $\begin{array}{l}0.99 \\
8 \\
0.95\end{array}$ & -0.625 & 0.5521 \\
\hline & $\begin{array}{l}2-4 \text { years } \\
\text { More than } 4 \\
\text { years }\end{array}$ & $\begin{array}{l}-0.17708 \\
-1.05208^{*}\end{array}$ & $\begin{array}{l}6 \\
0.3428 \\
6\end{array}$ & $\begin{array}{l}5 \\
0.01 \\
5 \\
0.99\end{array}$ & $\begin{array}{l}-1.0735 \\
-1.9485\end{array}$ & $\begin{array}{l}0.7194 \\
-0.1556\end{array}$ \\
\hline \multirow[t]{2}{*}{$1-2$ years } & $0-1$ years & 0.03646 & $\begin{array}{l}0.2251 \\
0.3573\end{array}$ & $\begin{array}{l}8 \\
0.97\end{array}$ & -0.5521 & 0.625 \\
\hline & $\begin{array}{l}2-4 \text { years } \\
\text { More than } 4 \\
\text { years }\end{array}$ & $\begin{array}{l}-0.14063 \\
-1.01563^{*}\end{array}$ & $\begin{array}{l}3 \\
0.3573 \\
3 \\
0.3428\end{array}$ & $\begin{array}{l}9 \\
0.02 \\
8 \\
0.95\end{array}$ & $\begin{array}{l}-1.0749 \\
-1.9499\end{array}$ & $\begin{array}{l}0.7937 \\
-0.0813\end{array}$ \\
\hline $2-4$ years & $0-1$ years & 0.17708 & $\begin{array}{l}6 \\
0.3573\end{array}$ & $\begin{array}{l}5 \\
0.97\end{array}$ & -0.7194 & 1.0735 \\
\hline \multirow{4}{*}{$\begin{array}{l}\text { More than } 4 \\
\text { years }\end{array}$} & $\begin{array}{l}1-2 \text { years } \\
\text { More than } 4 \\
\text { years }\end{array}$ & $\begin{array}{l}0.14063 \\
-0.875\end{array}$ & $\begin{array}{l}3 \\
0.4411 \\
0.3428\end{array}$ & $\begin{array}{l}9 \\
0.20 \\
1 \\
0.01\end{array}$ & $\begin{array}{l}-0.7937 \\
-2.0283\end{array}$ & $\begin{array}{l}1.0749 \\
0.2783\end{array}$ \\
\hline & $0-1$ years & $1.05208^{*}$ & $\begin{array}{l}6 \\
0.3573\end{array}$ & $\begin{array}{l}5 \\
0.02\end{array}$ & 0.1556 & 1.9485 \\
\hline & $1-2$ years & $1.01563^{*}$ & 3 & $\begin{array}{l}8 \\
0.20\end{array}$ & 0.0813 & 1.9499 \\
\hline & 2-4 years & 0.875 & 0.4411 & 1 & -0.2783 & 2.0283 \\
\hline
\end{tabular}




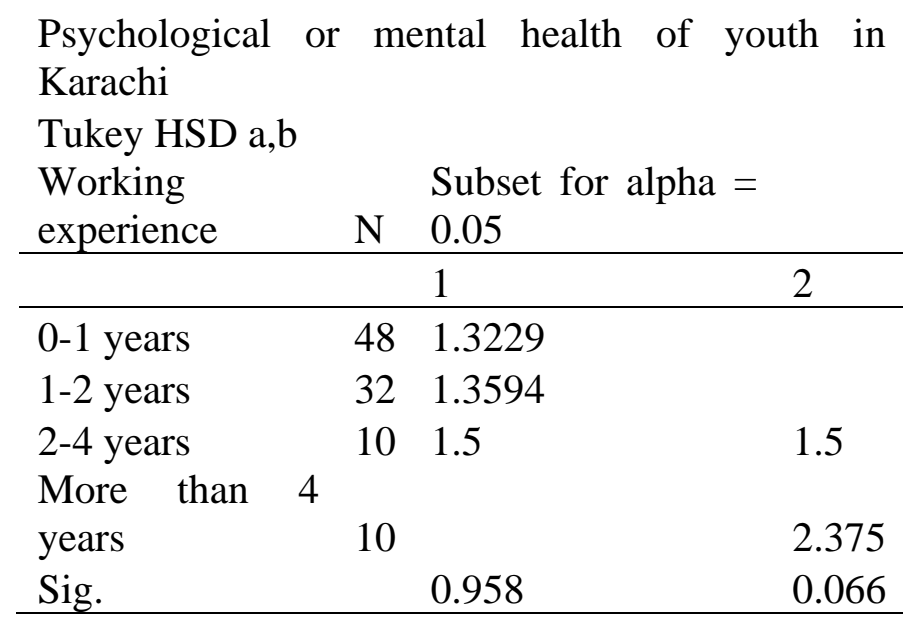

\section{Correlation analysis}

In the subsequent stage, correlation analysis was conducted through SPSS, which deciphered the statistical association of variables with each other. Pearson coefficient " $r$ " was used to test the significance, whose value ranges from -1 to 0 to +1 . An R-value of 0 to 0.3 shows weak association, from 0.4-0.6 shows moderate association, while from 0.7 to 1.0 indicates high association. The results are summarised in the following table. Analysis revealed that academic purposes have weak association with psychological or mental health of youth in Karachi. It means that the role of social media for academic purposes does not have statistically strong association, and hence, may not be strongly contributively to the mental health of young people. On the other hand, the socialisation factor of social media was found to have a high and positive significance with a correlation coefficient of 0.908 . The result is verification of the initial hypothesis that social media provides a substantial platform for socialisation to young people, and is closely associated with their mental health in social relations aspect. In furtherance, the association of entertainment aspect of social media was also found to be high with a coefficient of 0.987 , indicating that social media entertainment is highly associated with metal health of people. This aspect is also highly associated with the socialisation aspect of intendent variable with a coefficient of 0.874 .

Meanwhile, the aspect of informativeness of social media and its association with psychological or mental health of youth in Karachi has been identified to be strong and positive with a Pearson coefficient of 0.787 . While its association with other variables is also high, however, it is relatively lower compared to the independent variables of socialisation and entertainment. This could be attributed to multitude of information generated and made avowable to individuals which limits their ability to discern factual information from subjective opinions, and in worse case, fake news. Due to this, individuals who directly or indirectly get exposed to this aspect of social media report a higher mental health issue compared to those with no exposure. Meanwhile, analysis of the literature also indicated a rising distrust of internet news emerging among some groups of young population across the world. Although this trend is more 
pronounced in developed countries with high literacy and technology permeation rate, youth in Karachi could also be experiencing this phenomenon due to its highly urban setting and large internet connectivity. Whereas, the association of constraints with psychological health was found to be positive and strong.

Correlations

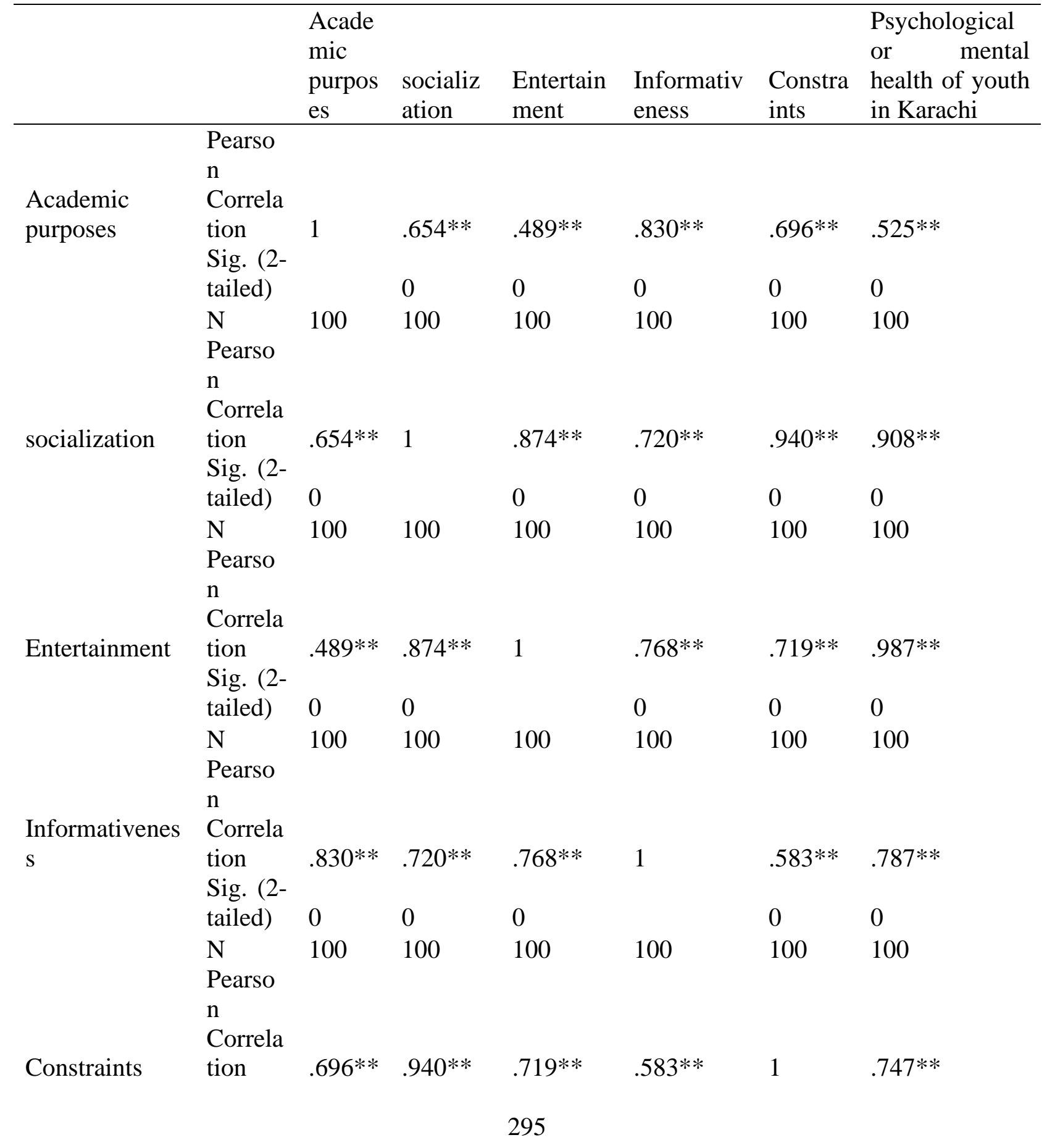


An Analytical View of the Psychological ...

Sig. (2-

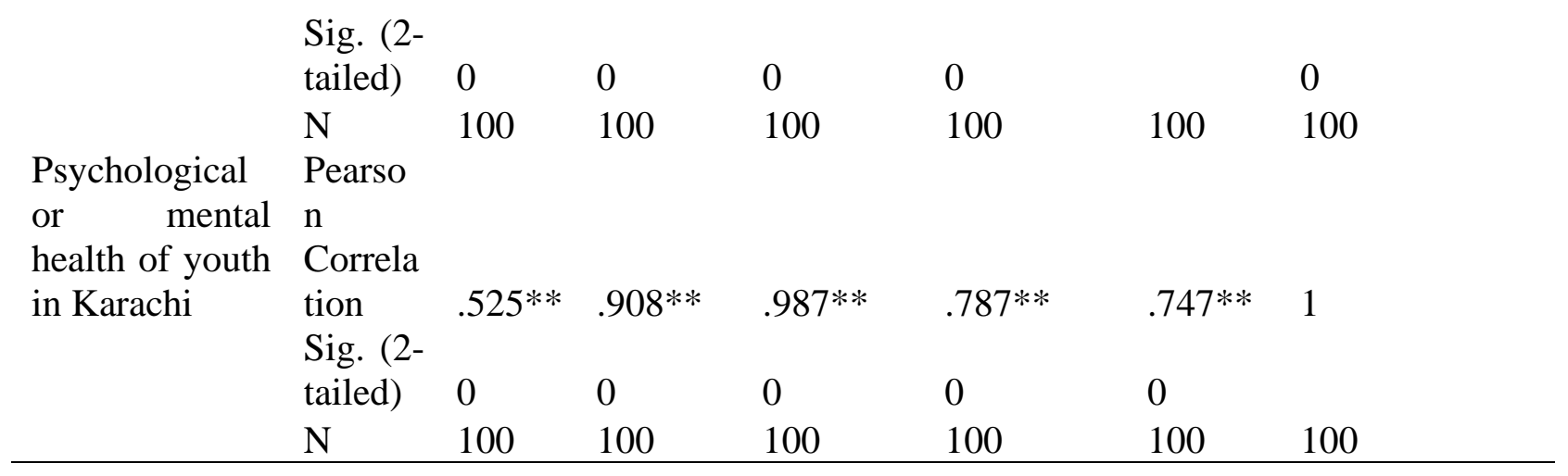

Psychological Pearso

or mental $n$

health of youth Correla

in Karachi tion

Sig. (2-

tailed)

$\mathrm{N} \quad 100 \quad 100$

An Analytical View of the Psychological ...

\section{Reliability and validity test}

Reliability and validity of the obtained data is paramount for credible scientific research. In social science research involving primary quantitative method, reliability and validity of data directly depends upon high reliability of the questionnaire designed. For this purpose, reliability and validity of the questionnaire is tested statistically with the help of Cronbach's alpha method in SPSS. For the current study, Cronbach's alpha test produced the following results.

\begin{tabular}{llll}
\multicolumn{3}{l}{ Reliability } \\
\multicolumn{3}{ll}{ Case Processing Summary } \\
& & \multicolumn{2}{l}{} \\
\hline Cases & Valid & 100 & 100 \\
& Excludeda & 0 & 0 \\
& Total & 100 & 100 \\
\hline
\end{tabular}

As expressed in the case processing summary, validity test of the questionnaire indicates whether the questions included find out that was desired to be found out. For this, the table shows a $100 \%$ validity because no question was excluded as non-targeting the intended aim of the study. Meanwhile, the value of Cronbach's alpha coefficient was obtained to be 0.95 , which indicates high statistical reliability of the test questionnaire.

\begin{tabular}{lll}
\multicolumn{2}{l}{ Reliability Statistics } \\
\hline $\begin{array}{l}\text { Cronbach's } \\
\text { Alpha }\end{array}$ & $\begin{array}{l}\text { Cronbach's Alpha Based on Standardized } \\
\text { Items }\end{array}$ & $\begin{array}{l}\mathrm{N} \text { of } \\
\text { Items }\end{array}$ \\
\hline 0.95 & 0.946 & 27 \\
\hline
\end{tabular}




\section{Discussion}

From literature analysis, it was found that this social accessibility is an opportunity for the community to connect all over the world but has social issues in developing countries such as Pakistan (Anam Iqbal \& Iqbal, K., 2017). For this reason, the country has the responsibility of accountability and investigation to make things better and effective. However, the current study found out that there exist inherent systemic hurdles in ensuring that every individual of the society gets access to the maximum benefit of worldwide connectivity without any discrimination. Firstly, the study found that social media imparts particularly adverse effects on mental heath of young individuals in Karachi city. This could be attributed to the fact that awareness of mental health issues and their identification is still an emerging field of healthcare in the country. Although a metropolitan city like Karachi is expected to score substantially higher in mental health awareness, however, several studies indicate otherwise, leading to a general disregard of psychological problems faced by the young generation (Hassan et al., 2012; Ali et al., 2013; Asim et al., 2021; Ahmer et al.,2018). This disregard culminates in the form of significant reduction in productivity that could be achieved through the current demographic dividend. The situation gets aggravated due to presence of unwanted websites and social media platforms which evidently harm psychological health in the mid and long term. These include online platforms of sexual content, regarding which, an experiment in Karachi showed that 57\% of young individuals between the age of 09 and 19 years were found to be indulgent on such platforms (Rabia et al., 2020). However, the current research indicated substantial positive impact of social media as well, in which the relation of informativeness and academic purpose was found to be high with reducing mental health issue in the youth of the city.

\section{Conclusion}

Social media has emerged as the leading platform to provide socialisation, information, and entertainment opportunities to the people. With worldwide connectivity, individuals are able to enjoy from the entertainment content, and benefit from academic pursuits from programs across the world. However, such an expedited rise is concomitant with emergence of personal and societal issues. Impact of social media on mental health of people has been a subjective of extensive research in recent years. For this purpose, the current study aimed at analysing psychological impact of social media on the youth of the city of Karachi. The researcher contextualised this study for the case of Karachi because of unique composition and urban dynamics of the city. The study employed a primary quantitative research design in which a total of hindered participants was approached for gathering their survey responses. The survey was done to obtain relation between impact of social media as the independent variable and psychological health of youth as dependent variable. For this, five dimensions were selected i.e., academic purposes, socialisation, entertainment, informativeness, and constraints. Statistical tests indicated that academic purpose has a low association with mental health of Karachi youth. 
Whereas, association of other four dimensions with mental health was found to be high and statistically positive.

\section{Recommendations}

From the study, it is recommended that government and local private stakeholders should imitate mental health awareness program in the youth and make them cognisant of the correct usage of social media. Moreover, the stakeholders should also use social media itself to promote healthy usage by engaging the youth in meaningful activities on virtual platforms. 


\section{References}

Ahmed, S., Ara, A., \& Tajjamul, S. (2016). Media Multitasking: An Exploratory Study on Students' Multiple Media Uses and Behaviours in Karachi. Journal of Mass Communication Department, Dept of Mass Communication, University of Karachi, 15.

\section{Anam Iqbal, A. A., \& Iqbal, K. (2017). FACTOR ANALYSIS OF EFFECTS OF SOCIAL} MEDIA ON YOUTH: A CASE STUDY OF UNIVERSITY OF SARGODHA.

Arendt, F., Scherr, S., \& Romer, D. (2019). Effects of exposure to self-harm on social media: Evidence from a two-wave panel study among young adults. New Media \& Society, 21(1112), 2422-2442.

Asibong, U., Okafor, C. J., Asibong, I., Ayi, E., Omoronyia, O., \& Owoidoho, U. (2020). Psychological distress and social media usage: A survey among undergraduates of a university in Calabar, Nigeria. Nigerian Postgraduate Medical Journal, 27(2), 115.

Bibi, A., Blackwell, S. E., \& Margraf, J. (2021). Mental health, suicidal ideation, and experience of bullying among university students in Pakistan. Journal of health psychology, 26(8), 1185-1196.

Glazzard, J., \& Stones, S. (2019). Social media and young people's mental health. In Selected Topics in Child and Adolescent Mental Health. IntechOpen.

Gupta, P., \& Purohit, N. (2020). Promoting Health Behavior in Young People in India: Learning for use of Social Media. International Journal of Behavioral Sciences, 14(3), 122-130.

Infographic: Mental Health: The Impact of Social Media on Young People. Statista Infographics. (2021). Retrieved 12 November 2021, from https://www.statista.com/chart/19262/impactof-social-media-on-mental-health/.

Lee, J. (2021). Pathways from childhood bullying victimization to young adult depressive and anxiety symptoms. Child Psychiatry \& Human Development, 52(1), 129-140.

Malik, A., Dhir, A., Kaur, P., \& Johri, A. (2020). Correlates of social media fatigue and academic performance decrement: a large cross-sectional study. Information Technology \& People.

Marchant, A., Hawton, K., Stewart, A., Montgomery, P., Singaravelu, V., Lloyd, K., ... \& John, A. (2017). A systematic review of the relationship between internet use, self-harm and 
suicidal behaviour in young people: The good, the bad and the unknown. PLoS one, 12(8), e0181722.

Mustafa, S. (2018). A Descriptive Study for the Impacts of Using Social Media on the Studies of University Students in Pakistan (A Literature Review.). European Scientific Journal, ESJ, 14, 18.

Mustafa, S. (2018). A Descriptive Study for the Impacts of Using Social Media on the Studies of University Students in Pakistan (A Literature Review.). European Scientific Journal, ESJ, 14, 18.

Rabia, M., Adnan, S., Misbah, N., Nawaz, H., Gillani, M., \& Arshad, A. (2020). Influence of Social Media on Youngsters: A Case Study in GC Women University Sialkot, Pakistan. Creative Education, 11(03), 285.

Sabermajidi, N., Valaei, N., Balaji, M. S., \& Goh, S. K. (2019). Measuring brand-related content in social media: a socialization theory perspective. Information Technology \& People.

Sheikh, F., Sheikh, S. S., \& Soomro, A. B. (2016). Social Media usage among University Students at the University of Sindh Jamshoro. Journal of Mass Communication Department, Dept of Mass Communication, University of Karachi, 15.

Sultana, Y., Ghaffar, S., \& Saman, S. (2019). Impact of excessive use of Facebook on the youth of Karachi. Journal of Social Sciences and Humanities, 58(2), 137-161.

Tahir, A., Baig, L. A., \& Ahmer, Z. (2020). Does watching violent electronic and social media content lead to increased levels of aggression? A survey among adolescents in an urban slum of metropolitan Karachi. International journal of adolescent medicine and health.

Tariq, W., Mehboob, M., Khan, M. A., \& Ullah, F. (2012). The impact of social media and social networks on education and students of Pakistan. International Journal of Computer Science Issues (IJCSI), 9(4), 407.

The Psychological Effects of Social Media on Teens. Newport Academy. (2021). Retrieved 12 November 2021, from https://www.newportacademy.com/resources/mentalhealth/psychological-effects-of-social-media/.

Wirth, K. (2020). Cyberbullying: Social Media Dangers to Teens and Young Adults (Doctoral dissertation, Utica College). 
Arikan, G., Acar, I. H., \& Ustundag-Budak, A. M. (2022). A two-generation study: The transmission of attachment and young adults' depression, anxiety, and social media addiction. Addictive Behaviors, 124, 107109.

Sarwar, B., Zulfiqar, S., Aziz, S., \& Ejaz Chandia, K. (2019). Usage of social media tools for collaborative learning: The effect on learning success with the moderating role of cyberbullying. Journal of Educational Computing Research, 57(1), 246-279.

Krosnick, J. A. (2018). Questionnaire design. In The Palgrave handbook of survey research (pp. 439-455). Palgrave Macmillan, Cham. 
